\title{
Transfer of Methanococcus frisius to the Genus Methanosarcina as Methanosarcina frisia comb. nov.
}

\author{
KARL-HEINZ BLOTEVOGEL ${ }^{1 *}$ AND ULRICH FISCHER ${ }^{2}$ \\ Fachbereich Biologie, AG Mikrobiologie, ${ }^{1}$ and Fachbereich Biologie, AG Geomikrobiologie, ${ }^{2}$ \\ Universität Oldenburg, D-2900 Oldenburg, Federal Republic of Germany
}

\begin{abstract}
Several methanogenic bacteria that utilize methanol, acetate, or methylamines have been isolated from marine habitats, including Methanococcus frisius. However, the 1984 description by Mah and Kuhn of the genus Methanococcus excludes methylotrophic methanebacteria such as Methanococcus frisius. Therefore, we propose to transfer this species to the genus Methanosarcina, naming it Methanosarcina frisia comb. nov. (type strain, DSM 3318 [= ATCC 43330]). Other species having similar properties (e.g., Methanococcus halophilus) should be assignable to Methanosarcina.
\end{abstract}

All species of the order Methanococcales (Methanococcus vannielii, Methanococcus voltae, Methanococcus maripaludis, Methanococcus deltae, Methanococcus thermolithotrophicus, Methanococcus jannaschii) share a coccoid morphology and a marine habitat (for a review see reference 4). With the exception of the thermophilic strains Methanococcus thermolithotrophicus and Methanococcus jannaschii, the species are mesophilic. Among these mesophilic species the physiological characteristics are very similar, including the utilization of $\mathrm{H}_{2}$ and formate as the only methanogenic substrates. In addition, temperature optima and deoxyribonucleic acid base compositions (guanineplus-cytosine contents) are similar. The cell envelopes are mainly composed of a protein monolayer (4).

The genus Methanococcus was described in detail by Mah and Kuhn (5). These authors pointed out that energy for cumscription of this genus, because this organism utilizes mainly methanol and methylamines but not formate; this is a metabolic behavior that is also common to Methanococcus halophilus $(9,10)$. Additionally, no flagella were observed, in contrast to the presence of flagella on species of the Methanococcaceae. Both Methanococcus frisius and $\mathrm{Me}$ thanococcus halophilus should be transferred to another genus, a suggestion supported recently by Rouvière and Wolfe (7). These authors showed that the molecular sizes of the methylreductase subunits of Methanococcus frisius are unequivocally similar to those of the members of the genus Methanosarcina. Antigenic fingerprinting has been undertaken (K.-H. Blotevogel and A. J. L. Macario, Syst. Appl. Microbiol,, in press) and has shown no relationship of Methanococcus frisius to members of the Methanococcaceae; there were slight cross-reactions with Methanosarcina

TABLE 1. Comparison of the main characteristics of known species of coccoid methanogens

\begin{tabular}{|c|c|c|c|c|c|c|}
\hline Species & Morphology & Substrates & $\begin{array}{l}\text { Guanine-plus-cytosine } \\
\text { content }(\mathrm{mol} \%)\end{array}$ & $\begin{array}{c}\text { Temp } \\
\text { optimum }\left({ }^{\circ} \mathrm{C}\right)\end{array}$ & $\begin{array}{c}\mathrm{pH} \\
\text { optimum }\end{array}$ & $\begin{array}{l}\text { Salt requirement } \\
(\% \mathrm{NaCl})\end{array}$ \\
\hline Methanococcus vannielii ${ }^{a}$ & Coccus & $\mathrm{H}_{2}$, formate & 32.5 & $36-40$ & $7.0-9.0$ & $1.2-4.8$ \\
\hline Methanococcus halophilus ${ }^{b}$ & Coccus & Methanol, methylamines & $\mathrm{ND}^{c}$ & $26-36$ & $6.5-7.4$ & $7.0-9.0$ \\
\hline Methanosarcina barkeri ${ }^{d}$ & $\begin{array}{l}\text { Coccus } \\
\quad \text { (packets) }\end{array}$ & $\begin{array}{l}\mathrm{H}_{2} \text {, methanol, } \\
\text { methylamines, acetate }\end{array}$ & 39 & 35 & 7.0 & $\mathrm{NR}^{e}$ \\
\hline Methanosarcina frisia ${ }^{f}$ & Coccus & $\begin{array}{l}\mathrm{H}_{2} \text {, methanol, } \\
\text { methylamines }\end{array}$ & 38.2 & 36 & $6.5-7.2$ & $2.0-2.5$ \\
\hline Methanosarcina acetivroans ${ }^{g}$ & $\begin{array}{l}\text { Coccus } \\
\quad \text { (aggregates) }\end{array}$ & $\begin{array}{l}\text { Acetate, methanol, } \\
\text { methylamines }\end{array}$ & 41 & $35-40$ & $6.5-7.0$ & 1.2 \\
\hline
\end{tabular}

${ }^{a}$ Data from reference 5 .

$b$ Data from reference 9 .

c ND, Not determined.

${ }^{d}$ Data from reference 4.

e NR, Not required.

${ }^{f}$ Data from reference 2 .

${ }^{g}$ Data from reference 8 .

growth of members of the family Methanococcaceae is obtained only by oxidation of $\mathrm{H}_{2}$ or formate coupled to the reduction of $\mathrm{CO}_{2}$ to $\mathrm{CH}_{4}$. They excluded methylotrophic growth for all species within the genus Methanococcus. Therefore, Methanococcus frisius (2) falls outside the cir-

\footnotetext{
* Corresponding author.
}

barkeri MS and W, Methanosarcina mazei S6, and Methanosarcina thermophila TM1.

Therefore, we propose that Methanococcus frisius be placed in the genus Methanosarcina of the Methanosarcinaceae. Morphology and substrate range clearly place Methanococcus frisius outside the genus Methanothrix, and the optimum salinity for growth places it outside the genus Methanohalophilus $(3,6)$. Differentiation from Methanococ- 
coides and Methanolobus depends on the ability of Methanococcus frisius to use $\mathrm{H}_{2}-\mathrm{CO}_{2}$, methanol, and methylamines.

The main differences among Methanococcus vannielii, Methanococcus halophilus, Methanosarcina barkeri, Methanosarcina frisia, and Methanosarcina acetivorans are summarized in Table 1 . As Table 1 shows, the major differences between Methanosarcina acetivorans and $\mathrm{Me}$ thanosarcina frisia are (i) the formation of aggregates by Methanosarcina acetivorans, (ii) the ability of Methanosarcina acetivorans to use acetate, (iii) no use of $\mathrm{H}_{2}-\mathrm{CO}_{2}$ and a lower salt requirement $(1.2 \% \mathrm{NaCl})$ by Methanosarcina acetivorans, and (iv) a higher guanine-plus-cytosine molar ratio in Methanosarcina acetivorans.

On the basis of the above-mentioned arguments, we transfer Methanococcus frisius to the genus Methanosarcina and name it Methanosarcina frisia comb. nov.

Description of Methanosarcina frisia comb. nov. Methanosarcina frisia (fri'si.a. f. derivative of L. masc. adj. frisius, pertaining to Frisia, a region in the northwest of the Federal Republic of Germany). Cells are fragile, regular cocci (diameter, 0.5 to $2.0 \mu \mathrm{m}$ ) and occur singly or in pairs, never in aggregates. The cells are gram negative and possess no flagella but exhibit fimbrialike structures. The cell envelope consists only of a single layer of protein subunits similar to that of Methanosarcina acetivorans (8). In addition, Methanosarcina frisia is serologically distinct from other coccoid methanogenic genera, such as Methanogenium, Methanoplanus, Methanosphaera, Methanolobus, and Methanococcus (Blotevogel and Macario, in press). Methanosarcina frisia grows in temperature range from 22 to $42^{\circ} \mathrm{C}$, with optimum growth at $36^{\circ} \mathrm{C}$. The $\mathrm{pH}$ optimum is between 6.5 and 7.2.

The DNA base composition is $38.2 \pm 1.0 \mathrm{~mol} \%$ guanine plus cytosine. The organism is strictly anaerobic and grows in a defined mineral medium with $\mathrm{H}_{2}-\mathrm{CO}_{2}$, methanol, or methylamines. Acetate and formate are not used. Yeast extract stimulates growth. Sodium chloride is required (at least $20 \mathrm{~g} /$ liter). The habitat is the shoal mud of marine environments.

The type strain of Methanosarcina frisia is strain DSM
3318 (= ATCC 43330), which was isolated from the black mud of the Leybucht (North Sea) (2).

We gratefully acknowledge Hans G. Trüper, Institut für Mikrobiologie, Universität Bonn, Federal Republic of Germany, for his interest and for suggesting the specific epithet.

\section{LITERATURE CITED}

1. Balch, W. E., G. E. Fox, L. J. Magrum, C. R. Woese, and R. S. Wolfe. 1979. Methanogens: reevaluation of a unique biological group. Microbiol. Rev. 43:260-296.

2. Blotevogel, K. H., U. Fischer, and K. H. Lüpkes. 1986. Methanococcus frisius sp. nov., a new methylotrophic marine methanogen. Can. J. Microbiol. 32:127-131.

3. Huser, B. A., K. Wuhrmann, and A. J. B. Zehnder. 1982 Methanothrix soehngenii gen. nov. sp. nov., a new acetotrophic non-hydrogen oxidizing methane bacterium. Arch. Microbiol. 132:1-9.

4. Jones, W. J., D. P. Nagle, Jr., and W. B. Whitman. 1987 Methanogens and the diversity of archaebacteria. Microbiol. Rev. 51:135-177.

5. Mah, R. A. and D. A. Kuhn. 1984. Transfer of the type species of the genus Methanococcus to the genus Methanosarcina naming it Methanosarcina mazei (Barker 1936) comb. nov. et emend. and conservation of the genus Methanococcus (Approved Lists 1980) with Methanococcus vannielii (Approved Lists 1980) as the type species. Int. J. Syst. Bacteriol. 34:263265

6. Paterek, J. R., and P. H. Smith. 1988. Methanohalophilus mahii gen. nov., sp. nov., a methylotrophic halophilic methanogen. Int. J. Syst. Bacteriol. 38:122-123.

7. Rouvière, P. E., and R. S. Wolfe. 1987. Use of subunits of the methylreductase protein for taxonomy of methanogenic bacteria. Arch. Microbiol. 148:253-259.

8. Sowers, K. R., S. F. Baron, and J. G. Ferry. 1984. Methanosarcina acetivorans $\mathrm{sp}$. nov., an acetotrophic methane-producing bacterium isolated from marine sediments. Appl. Environ. Microbiol. 47:971-978.

9. Zhilina, T. N. 1983. New obligate halophilic methane-producing bacterium. Mikrobiologiya 52:375-382.

10. Zhilina, T. N., and V. V. Kevbrin. 1985. Culturing a halophilic methane-forming coccus on monomethylamine. Mikrobiologiya 54:93-99. 